ORIGINAL ARTICLE / ARTIGO ORIGINAL

\title{
Body image and extreme attitudes toward weight in Brazilian schoolchildren (PeNSE 2012)
}

\author{
Imagem corporal e atitudes extremas em relação \\ ao peso em escolares brasileiros (PeNSE 2012)
}

Rafael Moreira Claro', Maria Aline Siqueira Santos", Maryane Oliveira-Campos"

\begin{abstract}
Introduction: Adolescence is a period characterized by changes such as accelerated physical growth and sexual development. Besides having to deal with these changes, adolescents are faced with beauty standards and extreme valorization of physical appearance. Objective: This article aims to describe body image and the practice of extreme attitudes regarding weight in Brazilian students. Methods: Data from the National Survey of School Health (PeNSE) 2012 were used in this study. PeNSE 2012 has a representative sample of students in the $9^{\text {th }}$ grade of elementary school in public and private schools across the country. A self-administered questionnaire on body image, practice of extreme measures in relation to weight and sociodemographic data was used. Body image and the practice of extreme attitudes were described for the total sample and according to gender. Poisson regression analyzes were used to identify differences in the practices of extreme attitudes between the different types of body image. Results: More than $38 \%$ of the adolescents did not consider their body image as normal. Over $15 \%$ of the students referred to carry out extreme weight control practices, combining practices to loose and gain weight. Adolescents who considered themselves fat presented frequency of extreme practices for weight loss $92 \%$ higher than that shown by individuals who considered themselves normal. Similarly, adolescents who considered themselves thin presented frequency of extreme attitudes to gain weight $(9.7 \%)$ higher than that shown by students who considered themselves normal (5.6\%). Conclusions: The high frequency of extreme weight control practices among Brazilian adolescents is alarming and should be subject of measures in health and education fields.
\end{abstract}

Keywords: Body image. Body weight. Adolescent. School health. Pharmaceutical preparations. Laxatives. Anabolic agents.

'Nutrition Department of Universidade Federal de Minas Gerais - Belo Horizonte (MG), Brazil.

"Department of Non-Communicable Disease Surveillance and Health Promotionof the Health Surveillance Secretariat of the Ministry of Health - Brasília (DF), Brazil.

Corresponding author: Rafael Moreira Claro. Universidade Federal de Minas Gerais, Escola de Enfermagem, Departamento de Nutrição. Avenida Alfredo Balena, 190, CEP: 30130-100, Belo Horizonte, MG, Brasil. E-mail: rafael.claro@gmail.com

Conflict of interests: nothing to declare - Financing source: none. 
RESUMO: Introdução: A adolescência é um período caracterizado por mudanças, como o acelerado crescimento físico e o desenvolvimento sexual. Além de ter que lidar com as transformações, os adolescentes deparam-se com os padrões de beleza e extrema valorização da aparência física. Objetivo: O objetivo deste artigo é descrever a imagem corporal e a realização de atitudes extremas em relação ao peso entre escolares do Brasil. Métodos: Dados da Pesquisa Nacional de Saúde do Escolar (PeNSE) 2012 foram utilizados neste estudo. A PeNSE 2012 conta com amostra representativa de alunos do $9^{\circ}$ ano do ensino fundamental de escolas públicas e privadas de todo o país. Utilizou-se questionário autoaplicável com questões sobre imagem corporal, realização de medidas extremas em relação ao peso e dados sociodemográficos. A imagem corporal e a realização de medidas extremas foram descritas para o conjunto total da população e segundo o sexo. Análises de regressão de Poisson foram utilizadas para identificar diferenças na realização de medidas extremas entre os diferentes tipos de imagem corporal. Resultados: Pouco mais de 38\% dos adolescentes não consideravam sua imagem corporal como normal. Mais de $15 \%$ dos escolares referia realizar práticas extremas para controle do peso, somadas às práticas para perda e ganho de peso. Adolescentes que se consideravam gordos apresentaram frequência de realização de práticas extremas para perda de peso $92 \%$ superior àquela apresentada por indivíduos que se consideravam normais. Do mesmo modo, adolescentes que se consideravam magros apresentaram frequência de realização de medida extrema para ganho de peso $(9,7 \%)$ superior àquela dos que se consideravam normais (5,6\%). Conclusões: A alta frequência de realização de práticas extremas para controle de peso entre os adolescentes brasileiros é alarmante e deve ser alvo de medidas na área tanto de saúde quanto de educação.

Palavras-chave: Imagem corporal. Peso corporal. Adolescente. Saúde Escolar. Preparações farmacêuticas. Laxantes. Anabolizantes.

\section{INTRODUCTION}

Adolescence is characterized by accelerated physical growth and sexual development ${ }^{1}$. Besides having to deal with the expected transformations for the period, adolescents are faced with beauty patterns and extreme valorization of appearance, which can results in unreal internalizations and consequent increasing insecurity, anxiety and dissatisfaction towards the body².

Body image refers to thoughts and feelings of an individual with regard to his or her body $^{3}$, and it can be influenced by several factors, such as the media, parents and friends in all stages of life 4 . The inadequacy between the ideal and the perceived body may lead to increasing predisposition to being dissatisfied with regard to body image ${ }^{5}$, and this feeling is acknowledged as a general problem experienced by an expressive portion of adolescents, as demonstrated in national and international studies ${ }^{6,7}$.

This context is related to the higher predisposition of adolescents to depression, among other health-related problems $s^{8}$. Besides, the dissatisfaction towards body image may lead adolescents to adopt extreme practices, such as restricted diets for weight loss ${ }^{9}$, use of 
medicines, laxatives, induced vomit, thus making them more prone to severe nutrition disorders, such as anorexia, bulimia nervosa ${ }^{10-12}$. Likewise, other reported behaviors are the exaggerated practice of physical activity and the use of anabolic steroids, which are also related to body dysmorphic disorders ${ }^{13}$.

Considering the importance of having a positive body image andof healthy weightcontrol practices for the health of adolescents, this study aimed at describing body image and the conduction of extreme attitudes toward weight among the adolescents analyzed by the National Adolescent School-Based Health Survey (PeNSE) $2012^{14}$.

\section{METHODOLOGY}

\section{STUDY POPULATION, SAMPLE AND DATA COLLECTION}

This study used data collected from PeNSE, which was conducted from April and September, 2012. The objective of the study in 2012 was to assess the risk and protective factors for chronic diseases in a population of $9^{\text {th }}$ graders from elementary school, in public and private schools of Brazil ${ }^{14}$. The sample of PeNSE 2012 was developed to represent Brazil, its capitals and the five major geographic regions. Each of these strata had a sampling plan. Capitals had a two-stage cluster sample, being schools and their classrooms the primary and secondary sampling units, respectively. In the other cases, the primary unit was the group of cities; the secondary unit, schools; and the tertiary unit, the classrooms. Further details about the sampling process of PeNSE are described in the original publication of the results ${ }^{14}$.

Data collection was conducted by a palm computer (Personal Assistant), with a structured and self-applicable questionnaire divided in modules according to topic: sociodemographic characteristics, dietary habits, body image, physical activity, smoking, use of alcohol and other drugs, oral health, sexual behavior, violence, accidents and safety.

\section{DATA ORGANIZATION AND CONSTRUCTION OF INDICATORS}

Body image was investigated in PeNSE 2012 with the following question: "With regard to your body, do you consider being: very thin, thin, normal, fat and very fat". For the analysis, students were classified in three levels: thin (including thin and very thin), normal and fat (including fat and very fat).

The extreme weight-control practices investigated in PeNSE 2012 were: use of laxatives or vomit induction (obtained by the question: "In the past 30 days, did you vomit or use laxatives to lose weight or to avoid gaining weight? Yes/no"); use of medications or formulas to lose weight (obtained by the question "In the past 30 days, did you take any medication, formula or other product to lose weight or maintain your weight without medical recommendations? Yes/no"); and use of medications or formula to gain weight or muscle mass (obtained by 
the question "In the past 30 days, did you take any medication, formula or other product to gain weight or muscle mass without medical recommendations? Yes/no").

A set of sociodemographic characteristics about the analyzed students complement the data from PeNSE 2012, which are useful for the present study: sex (male and female); age group ( $\leq 13,14$ and 15 years old, $\geq 16$ years old); maternal schooling (incomplete elementary school, complete elementary school, incomplete high school, complete high school, incomplete higher education, and complete higher education); ethnicity/ color (black, white, mulatto, yellow, indigenous) school administration (public and private).

\section{DATA ANALYSIS}

Body image and the conduction of extreme weight-control practices were described for the total population and according to sex. Afterwards, the conduction of extreme weightcontrol practices was described according to the body image of the students.

The association between body image and the conduction of extreme weight-related attitudes was studied by Poisson regression models. At first, differences concerning the frequency of extreme attitudes were analyzed between different body image statuses for the entire studied population. Afterwards, the conduction of extreme practices was compared between boys and girls in three body image statuses. The differences between sexes were investigated by simple Poisson models (involving the extreme practice of interest as an outcome and the sex of the student as an explanatory variable), and by adjusted models (involving not only the previously mentioned variables, but also region, capital of residency, maternal schooling, school administration, age and color/ ethnicity of the student).

All of the analyses were made by respecting the design of the sample used in PeNSE 2012, with the assistance of the software Stata 12.1 (Stata Corp. College Station).

\section{ETHICAL ASPECTS}

PeNSE was approved by the National Research Ethics Committee (CONEP), register n. 16,805. The data made available by the Brazilian Institute of Geography and Statistics do not allow to identify the respondents, thus respecting secrecy.

\section{RESULTS}

About two thirds of the analyzed students lived in the Center-West region of the country $(66.8 \%)$, in regions located in the countryside (77.6\%). Most of them were between 14 and 15 years old (45.5\%), being boys older than girls. Besides, more than half of them claimed to be black/mulattos (55.6\%) and attended public schools (82.2\%). More than half of the 
students $(60.2 \%)$ were children of mothers with low schooling (incomplete elementary school, 42.2\%; and incomplete high school, $18 \%)$, and a bit more than 1 out of $10(11.2 \%)$ were children of mothers with complete higher education (Table 1).

Table 1. Sociodemographic characteristics of studentsin the $9^{\text {th }}$ grade by gender. PeNSE, 2012.

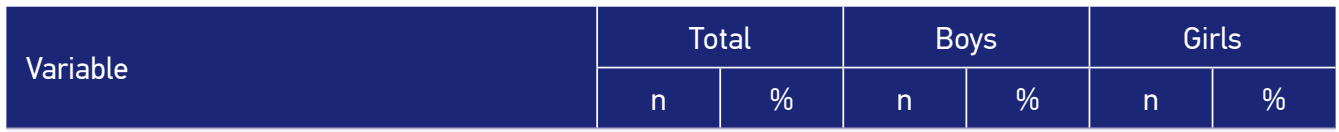

Region

\begin{tabular}{|c|c|c|c|c|c|c|}
\hline North & 22.774 & 8.0 & 10.574 & 7.6 & 12.200 & 8.3 \\
\hline Northeast & 31.301 & 25.3 & 14.355 & 23.4 & 16.946 & 27.0 \\
\hline Southeast & 19.660 & 44.3 & 9.685 & 46.2 & 9.975 & 42.6 \\
\hline South & 14.878 & 14.6 & 7.304 & 14.8 & 7.574 & 14.3 \\
\hline Center-West & 20.491 & 7.9 & 10.097 & 8.0 & 10.394 & 7.8 \\
\hline \multicolumn{7}{|l|}{ Type of city } \\
\hline Capital & 61.145 & 22.4 & 29.393 & 23.0 & 31.752 & 21.8 \\
\hline Non-capital & 47.959 & 77.6 & 22.622 & 77.0 & 25.337 & 78.2 \\
\hline \multicolumn{7}{|l|}{ Age (years) } \\
\hline$\leq 13$ & 22.443 & 22.9 & 9.148 & 19.8 & 13.295 & 25.8 \\
\hline $14-15$ & 50.900 & 45.5 & 23.240 & 43.9 & 27.660 & 47.1 \\
\hline$\geq 16$ & 35.761 & 31.6 & 19.627 & 36.3 & 16.134 & 27.2 \\
\hline \multicolumn{7}{|l|}{ Ethnicity } \\
\hline White & 37.674 & 36.8 & 18.770 & 38.7 & 18.904 & 35.0 \\
\hline Black/mulatto & 62.750 & 55.6 & 29.269 & 54.0 & 33.481 & 57.1 \\
\hline Yellow & 4.821 & 4.1 & 2.040 & 3.8 & 2.781 & 4.4 \\
\hline Indigenous & 3.790 & 3.5 & 1.900 & 3.6 & 1.890 & 3.5 \\
\hline \multicolumn{7}{|l|}{ Type of school } \\
\hline Private & 22.504 & 17.2 & 11.066 & 17.7 & 11.438 & 16.7 \\
\hline Public & 86.600 & 82.8 & 40.949 & 82.3 & 45.651 & 83.3 \\
\hline \multicolumn{7}{|l|}{ Maternal schooling (highestlevel) } \\
\hline Incomplete elementary school & 33.322 & 42.2 & 14.768 & 39.9 & 18.554 & 44.3 \\
\hline Incomplete high school & 15.975 & 18.0 & 7.615 & 18.3 & 8.360 & 17.7 \\
\hline Incomplete higher education & 28.244 & 28.7 & 13.745 & 29.6 & 14.499 & 27.8 \\
\hline Complete higher education & 13.332 & 11.2 & 6.901 & 12.2 & 6.431 & 10.2 \\
\hline
\end{tabular}


Table 2. Body image and attitude toward body weight in studentsin the $9^{\text {th }}$ grade by gender. PeNSE, 2012.

\begin{tabular}{|c|c|c|c|c|c|c|}
\hline \multirow{2}{*}{ Variable } & \multicolumn{2}{|c|}{ Total } & \multicolumn{2}{|c|}{ Boys } & \multicolumn{2}{|c|}{ Girls } \\
\hline & $\mathrm{n}$ & $\%$ & $n$ & $\%$ & $n$ & $\%$ \\
\hline \multicolumn{7}{|l|}{ Bodyimage } \\
\hline Thin or very thin & 24.373 & 21.9 & 11.727 & 22.2 & 12.646 & 21.6 \\
\hline Normal* & 66.339 & 61.9 & 33.183 & 64.7 & 33.156 & 59.3 \\
\hline Fat or very fat* & 17.853 & 16.3 & 6.788 & 13.1 & 11.065 & 19.1 \\
\hline \multicolumn{7}{|l|}{ Extreme weight-control practices } \\
\hline Use of laxatives or induced vomit & 6.416 & 6.1 & 2.773 & 5.7 & 3.643 & 6.4 \\
\hline $\begin{array}{l}\text { Use of medications (or formulas) for } \\
\text { weight loss* }\end{array}$ & 6.176 & 5.7 & 3.323 & 6.6 & 2.853 & 4.9 \\
\hline $\begin{array}{l}\text { Use of at least one of the mentioned } \\
\text { practices for weight loss }\end{array}$ & 9.908 & 9.2 & 4.666 & 9.3 & 5.242 & 9.1 \\
\hline $\begin{array}{l}\text { Use of medications (or formulas) for } \\
\text { weight gain (or muscle mass)* }\end{array}$ & 6.765 & 6.2 & 4.460 & 8.4 & 2.305 & 4.2 \\
\hline
\end{tabular}

*Statistically significant difference $(p<0.05)$ between sexes.

With regard to body image, most (61.9\%) students considered being normal. The frequency of students who considered themselves as being thin was similar between sexes (about 20\%), while the frequency of those who claimed to be fat was higher among girls $(19.1 \%)$ than boys $(13.1 \%)(\mathrm{p}<0.05)$. The conduction of at least one extreme practice for weight loss was reported by $9.2 \%$ of the students, with no differences between sexes. Among these practices, the use of laxatives or the act of inducing vomit was reported by $6.1 \%$ of the students, and there was no difference between sexes. A similar frequency to that identified for the consumption of medicines (or formulas) for weight loss was found (5.7\%). However, a higher frequency was identified among boys $(6.6 \%)$ than girls $(4.9 \%)(\mathrm{p}<0.05)$. The use of medications (or formulas) for weight gain (or muscle mass) was reported by $6.2 \%$ of the students, and the frequency was twice as high among boys $(8.4 \%)$ than girls $(4.2 \%)(\mathrm{p}<0.05)$ (Table 2$)$.

For the entire studied population, the use of at least one of the extreme weight-loss practices was more frequent $(15 \%)$ among students who considered being fat $(\mathrm{p}<0.05)$, and similar for the other groups. The frequency of use of medications (or formulas) for weight loss was lower among students who considered being normal (4.6\%), and equally high among those who considered to be thin or fat (respectively, 6.6 and $8.1 \%$ ), with no statistical difference between these groups, being both higher to the frequency observed for students who claimed to be normal. The frequency of students who reported the use of medications (or formulas) for weight gain was higher among students who considered being thins (Table 3 ). 
Table 3. Extreme attitudes toward weight according to body image in students in the $9^{\text {th }}$ grade by gender. PeNSE, 2012.

\begin{tabular}{|c|c|c|c|}
\hline Variable & $\operatorname{Thin}(\%)^{*}$ & Normal (\%)* & Fat $(\%)^{*}$ \\
\hline
\end{tabular}

Extreme weight-controlpractices

\begin{tabular}{l|c|c|c}
\hline Use of laxatives or induced vomit & $5.5^{* *}$ & $5.0^{* *}$ & $11.0^{\S}$ \\
\hline $\begin{array}{l}\text { Use of medications (or formulas) for } \\
\text { weight loss }\end{array}$ & $6.6^{\#}$ & $4.7^{\S}$ & $15.0^{\# \#}$ \\
\hline $\begin{array}{l}\text { Adoption of at least one of the mentioned } \\
\text { practices for weight loss }\end{array}$ & $8.9^{£}$ & $7.8^{£}$ & $3.9^{£ \varepsilon}$ \\
\hline $\begin{array}{l}\text { Use of medications (or formulas) for } \\
\text { weight gain(or muscle mass) }\end{array}$ & $9.7^{£ \varepsilon}$ & $5.6^{\S \S}$ & \\
\hline
\end{tabular}

Extreme weight-controlpractices

\begin{tabular}{|c|c|c|c|}
\hline Use of laxatives or induced vomit & $7.3^{\text {a.b }}$ & 4.9 & $6.8^{a . b}$ \\
\hline $\begin{array}{l}\text { Use of medications (or formulas) for } \\
\text { weight loss }\end{array}$ & $9.0^{a . b}$ & $5.7^{a . b}$ & $6.7^{\mathrm{a} . \mathrm{b}}$ \\
\hline $\begin{array}{l}\text { Adoption of at least one of the mentioned } \\
\text { practices for weight loss }\end{array}$ & $11.4^{\mathrm{a} \cdot \mathrm{b}}$ & $8.4^{\mathrm{a}}$ & $10.4^{\mathrm{a} . \mathrm{b}}$ \\
\hline $\begin{array}{l}\text { Use of medications (or formulas) for } \\
\text { weight gain(or muscle mass) }\end{array}$ & $12.1^{a . b}$ & $7.8^{\text {a.b }}$ & $5.4^{\mathrm{a} . \mathrm{b}}$ \\
\hline
\end{tabular}

Extreme weight-controlpractices

\begin{tabular}{l|c|c|c}
\hline Use of laxatives or induced vomit & $3.8^{\text {a.b }}$ & 5.0 & $13.6^{\text {a.b }}$ \\
\hline $\begin{array}{l}\text { Use of medications (or formulas) for } \\
\text { weight loss }\end{array}$ & $4.4^{\text {a.b }}$ & $3.8^{\text {a.b }}$ & $9.0^{\text {a.b }}$ \\
\hline $\begin{array}{l}\text { Adoption of at least one of the mentioned } \\
\text { practices for weight loss }\end{array}$ & $6.6^{\text {a.b }}$ & $7.2^{\text {a }}$ & $17.8^{\text {a.b }}$ \\
\hline $\begin{array}{l}\text { Use of medications (or formulas) for } \\
\text { weight gain(or muscle mass) }\end{array}$ & $7.4^{\text {abb }}$ & $3.3^{\text {a.b }}$ & $3.1^{\text {a.b }}$ \\
\hline
\end{tabular}

${ }^{*}$ Crude frequency of indicators in each of the conditions.

${ }^{* *} p<0.05$ in comparison with \&; ${ }^{\star} p<0.05$ in comparison with ${ }^{* *} ;{ }^{*} p<0.05$ in comparison with ${ }^{5} ;{ }^{\S} p<0.05$ in

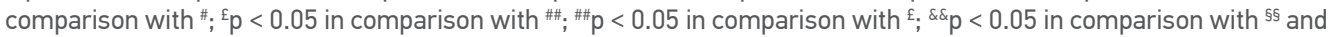

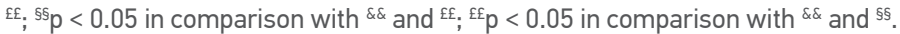

aCrudemodel: statisticallysignificantdifference $(p<0.05)$ between sex andoutcomesofinterest (presentedfrequency); badjustedmodel: statisticallysignificantdifference $(p<0.05)$ betweensexes for region, capital ofresidency, maternal schooling, schooladministration, age and color/ethnicityofthestudent (adjustedfrequency, notpresented). 
Among individuals who considered being thin and normal, a higher frequency was observed for all of the analyzed extreme practices — both for weight loss and gain — among boys when compared to girls. This difference was observed both in the crude comparison of frequencies and in the adjusted one for region, capital of residency, maternal schooling, school administration, age and ethnicity/color of the student. On the one hand, among students who considered themselves as being fat, boys presented higher frequency as to the use of medications for weight or mass gain, and, on the other, among girls, there were higher frequencies of extreme attitudes for weight loss (Table 3 ).

\section{DISCUSSION}

The performance of a survey representing $9^{\text {th }}$ graders all over the country enabled the identification of important aspects related to body image and the conduction of extreme weight-control practices among Brazilian students for the first time. More than one third of the students (a bit more than 38\%) did not consider their body image to be normal. Almost one sixth of the students reported using extreme weight-control practices, added to the practices for weight loss and gain. Among the ones who claimed to be fat, a higher frequency of weight-loss practices was observed among girls. Boys presented higher frequencies of weight-gain practices (or muscle mass) in relation to girls, regardless of their body image.

Our results show how dissatisfied Brazilian students are concerning their body image, and their reference is the ideal body pattern established by the current culture, which is widely publicized in means of communication - thin, but highly muscular for boys, and only thin for girls ${ }^{15,16}$. The covers in printed media, for instance, publicize a specific beauty pattern and usually invite the readers to change their bodies, especially by practicing physical activities, undergoing aesthetic treatments, diets and even plastic surgeries ${ }^{17}$.

A study conducted with 10 to 18-year old students, in São Paulo, about media and body, observed that, in $95 \%$ of the answers, teenagers identified the relationship between TV, magazines and body. This relationship was positive only for $9 \%$ of them, while, for the others, it reflected an obligation to search for perfect physical aspects or the stimulation to developing diseases and the sensation of humiliation ${ }^{18}$.

The persistent desire to become thinner and the fear of gaining weight lead to a reality of extreme concern and consequent behavioral change, such as eating restrictions, which can result in the use of laxatives and self-induced vomits ${ }^{19}$. In our study, adolescents who considered being fat conducted extreme weight-loss practices almost twice as much as the rates presented for individuals who considered being normal. It is possible to identify the importance of thinness among adolescents, or the fear of gaining weight, also in the high proportion of individuals who reported the use of medications of formulas for weight loss, even when they consider being thin or normal. 
The high frequency of extreme weight-control practices among adolescents had been diagnosed in small samples of the Brazilian population more than ten years ago ${ }^{20}$.

In a study with 1,807 students attending public schools, aged 7 to 19 years old, in the countryside of Minas Gerais, among interviewees who claimed to be dissatisfied about their body, $71 \%$ of the girls and $66 \%$ of the boys were on sporadic or frequent diets; $94.6 \%$ of the girls and $97.1 \%$ of the boys exercised to lose weight sporadically or frequently ${ }^{20}$. The high frequency of extreme weight-control practices identified in this study, in local range, could be seen as an indicator of the results presented in this study, in which more than $15 \%$ of the students reported the adoption of extreme weight-control practices.

Generally, it is possible to observe that girls prefer to skip meals, combined with a high frequency of diets and disorders ${ }^{21}$. Likewise, adolescents and grown women who think themselves to be fat tend to often adopt the practice of fasting and the use of laxatives as a way to detoxify the body ${ }^{22}$. Our results confirm the high prevalence of extreme weightloss practices among girls (about 10\%), and innovate by presenting equally high levels among boys. Data obtained from PeNSE 2009, conducted with $9^{\text {th }}$ graders from public and private schools of the 26 Brazilian State capitals and the Federal District, already indicated the severity of the topics analyzed here ${ }^{7}$. These data already showed the high frequency of students who were not satisfied about their body image (about $40 \%$ of them considered being thin or fat), as well as the conduction of extreme weight-control practices (about 7\%). The analysis of the tendency of results found in both studies is limited due to the differences in the analyzed populations and in the questionnaires used in PeNSE 2009 and 2012.

A higher frequency in the use of medications or formulas (both for weight gain and loss) was observed among boys, and about $8.4 \%$ of them reported taking medication for weight gain. It is a worrisome percentage, once the use of medications (or formulas) for weight gain or loss (or muscle mass) among adolescents has become a global problem ${ }^{23,24}$. The high frequency of medicine use with the objective of gaining muscle mass or losing body fat can be justified by the high level of satisfaction among adolescents toward their body image after gaining muscle mass ${ }^{25}$.

Even if the use of medications or formulas for weight loss among men is not common in scientific literature, the date presented here emphasize that it is important for this theme to be approached more effectively.

Indications of this behavior had been published among the results of PeNSE 20097, and also in studies with small local samples ${ }^{20}$. Hypotheses for this behavior include the fact that boys possibly have more access to these medications or a lower perception of the risks involved with their use.

It is also worth to mention the high frequency of weight-loss practices among individuals who considered being thin, which was higher among boys than girls. Even if our results do not allow identifying the real nutrition status of students, or even the 
time when the use of these medications started, it is natural to believe that this behavior can be an indication of the fear of gaining weight, even among those who consider being thin. In addition, it is not possible to identify if the respondents of PeNSE identified the thin self-image as a negative condition (that should be treated) or a desirable one (that should be maintained at any cost).

It is also noteworthy that the desire to lose or gain weight is often not in accordance with the real situation of body mass index of these teenagers, since the studies find the distorted body image reported by adolescents ${ }^{7}$. PeNSE 2009 presented information about the nutrition status of students (weight and height measured directly in the schools); besides the questions analyzed here concerning body image, it was also possible to analyze the concordance between these measurements ${ }^{7}$. A low concordance was observed between nutrition status and body image (kappa $=0.33$ ). Besides, almost half of the students with excessive weight considered to have adequate weight, and $27 \%$ of them considered being thin. Similarly, in a study conducted with 1,009 14 to 19-year old adolescents who attended one public school in São Paulo, the body perception was distorted from the real condition in both sexes, therefore, there was overestimation among girls (43.45\%) and underestimation among boys $(5.65 \%)^{23}$.

Some limitations of the results presented here should be observed. At first, it was not possible to analyze the accuracy concerning the assessment of body image performed by the students (comparing it to the objective measurement of their nutrition status), once the weight and height measurements were not part of the protocol in PeNSE 2012. Even if self-reported weight and height measurements had been obtained, preliminary analyses indicated its low validity, thus preventing their use (data not shown). In spite of that, the registered information is useful for the awareness of the students' perception toward body image, and the influence it has on the conduction of extreme weight-control practices. Besides, it is natural to believe that the results found for the concordance between nutrition status and body image, from PeNSE 2009 (previously mentioned) are still valid. Finally, it is important to mention that the conduction of extreme weightcontrol practices examined here cannot be directly understood as the representation of eating disorders, such as bulimia and anorexia nervosa ${ }^{7}$. The indicators presented here, after being investigated, can be used as a proxy for the vulnerability of these problems, but not for their diagnoses.

\section{CONCLUSION}

The influence of body image on the adoption of extreme weight-control practices in adolescence is a matter of concern among Brazilian adolescents. There are important gender-related differences when it comes to body image, and girls consider themselves as 
being fat more often. The adoption of extreme practices is more common among those who considered being fat and among boys. These data should be considered by those who work with adolescents, be it in the health or in the education field. Professionals should be prepared to approach the related themes better and to guide teenagers as to excessive concern about their bodies, body image and its consequences.

\section{REFERENCES}

1. Di Clemente RJ, Santelli JS, Crosby RA. Adolescent health: understanding and preventing risk behaviors. São Francisco: Jossey-Bass; 2009.

2. Vitolo MR, Bortolini GA, Horta RL. Prevalência de compulsão alimentar entre universitárias de diferentes áreas de estudo. Rev Psiquiatr RS 2005; 28(1): 20-6.

3. Slade PD. Body image and self-esteem among adolescents undergoing an intervention targeting dietary and physical activity behaviors body image in anorexia nervosa. Br J Psychiatry Suppl. 1988; (2): 20-2.

4. Damasceno VO, Vianna VRA, Vianna JM, Lacio M, Lima JRP, Novaes JS. Imagem corporal e corpo ideal. Rev Bras Ciên e Mov 2006; 14(1): 87-96.

5. Tucci S, Peters J. Media influences on body satisfaction in female students. Psicothema 2008; 20(4): 521-4.

6. Corseuil MW, Pelegrini A, Beck C, Petroski EL. Prevalência de insatisfação com a imagem corporal e sua associação com a inadequação nutricional em adolescentes. R da Educação Física/UEM 2009; 20(1): 25-31.

7. Castro IRR, Levy RB, Cardoso LO, Passos MD, Sardinha LMV, Tavares LF, et al. Imagem corporal, estado nutricional e comportamento com relação ao peso entre adolescentes brasileiros. Ciênc Saúde Coletiva 2010; 15(2): 3099-108.

8. Campagna VN, Souza ASL. Corpo e imagem corporal no início da adolescência feminina. Bol Psicol 2006; 55(124): 9-35.

9. Nicholls D, Viner R. Eating disorders and weight problems. BMJ 2005; 330: 950-3.

10. Keery H, Van den Berg P, Thompson JK. An evaluation of the Tripartite Influence Model of body dissatisfaction and eating disturbance with adolescent girls. Body Image 2004; 1(3): 237-51.

11. Shroff $\mathrm{H}$, Thompson JK. Peer influences, body image dissatisfaction, eating dysfunction and self-esteem in adolescent girls. J Health Psychol 2006; 11(4): 533-51.
12. McKnight Investigators. Risk factors for the onset of eating disorders in adolescente girls: results of the McKnight longitudinal risk factor study. Am J Psychiatry 2003; 160(2): 248-54.

13. Hunt TJ, Thienhaus O, Ellwood A. The mirror lies: body dysmorphic disorder. American Family Physician 2008; 78(2): 217-22.

14. Instituto Brasileiro de Geografia e Estatística. Pesquisa Nacional de Saúde do Escolar - PeNSE 2012. Rio de Janeiro: IBGE; 2013. Disponível em http: / www.ibge. gov.br/home/estatistica/populacao/pense/2012/ pense_2012.pdf. (Acessado em 29 de janeiro de 2014).

15. Hargreaves DA, Tiggemann M. Idealized media images and adolescent body image: "comparing" boys and girls. Body Image 2004; 1(4): 351-61.

16. Jones DC, Crawford JK. Adolescent boys and body image: weight and muscularity concerns as dual pathways to body dissatisfaction. Journal of Youth of Adolescent 2005; 34 (6): 629-36.

17. Maldonado GDR. A educação física e o adolescente: a imagem corporal e a estética da transformação na mídia impressa. Rev Mackenzie de Educação Física e Esporte 2006; 5(1): 59-76.

18. Conti MA, Bertolin MNT, Peres SV. A mídia e o corpo: o que o jovem tem a dizer? Ciênc Saúde Coletiva 2010; 15(4): 2095-103.

19. Alves E, Vasconcelos FAG, Calvo MCM, Neves J. Prevalência de sintomas de anorexia nervosa e insatisfação com a imagem corporal em adolescentes do sexo feminino do Município de Florianópolis, Santa Catarina, Brasil. Cad Saúde Pública 2008; 24(3): 503-12.

20. Vilela JEM, Lamounier JA, Dellaretti Filho MA, Neta JRB, Horta GM. Transtornos alimentares em escolares. J Pediatr (Rio J) 2004; 80(1): 49-54.

21. Braggion GF, Matsudo SMM, Matsudo VKR. Consumo alimentar, atividade física e percepção da aparência corporal em adolescentes. Rev Bras Ciên e Mov 2000; 8(1): 15-21. 
22. De Cicco MF, Santos NO, Silva MM, Laham C, Garrido Junior A, Lucia MCS. Imagem corporal, práticas de dietas e crenças alimentares em adolescentes e adultas. Psicol Hosp 2006; 4(1): 1-27.

23. Branco LM, Hilário MOE, Cintra IP. Percepção e satisfação corporal em adolescentes e a relação com seu estado nutricional. Rev Psiq Clín 2006; 33(6): 292-6.

24. Field EA, Austin SB, Camargo CA Jr, Taylor CB, Striegel-Moore RH, Loud KJ, et al. Exposure to the mass media, body shape concerns, and use of supplements to improve weight and shape among male and female adolescents. Pediatrics 2005; 116(2): e214-20.

25. Oliveira U. O uso de esteroides androgênicos anabolizantes entre adolescentes e a sua relação com a prática da musculação [tese de doutorado]. Campinas: Universidade Estadual de Campinas; 2012.

Received on: 02/26/2014

Final version presented on: 05/13/2014

Accepted on: 05/13/2014 